\title{
Mediation Effect of Resilience on The Relationship between Self-Efficacy and Competitiveness among University Students
}

\author{
Kingston K.F. Moke, Calvin K.W. Chang, Kususanto Prihadi, Chee Leong Goh \\ Department of Psychology, HELP University, Malaysia
}

\begin{tabular}{l} 
Article Info \\
\hline Article history: \\
Received Sep 25, 2018 \\
Revised Oct 3,2018 \\
Accepted Oct 14,2018 \\
\hline
\end{tabular}

Keyword:

Competitiveness

Mediation

Resilience

Self-Efficacy

\begin{abstract}
This study aimed to evaluate the mediation role of resilience on the link between self-efficacy and competitiveness among university students in Malaysia. One hundred and thirty-six participants from several universities in Malaysia were recruited to respond to an online form consisted of the following scales: adapted versions of brief resilience scale from Smith et al, self-efficacy scale from Biemann, Kearney and Marggraf, and Personal Development Competitive Attitude Scale from Ryckman, Hammer, Kaczor and Gold. Data was analyzed by using SPSS with PROCESS Macro and full mediation has been observed. Bias-corrected bootstrap confidence interval test indicated that the indirect effect of self-efficacy on competitiveness was significant and the Sobel test had confirmed the significance of the mediation. Further discussion, limitation and suggestion are discussed in the end of the paper.
\end{abstract}

Copyright (C) 2018 Institute of Advanced Engineering and Science. All rights reserved.

\section{Corresponding Author:}

Kususanto Prihadi, Department of Pshycology, HELP University Subang 2,

No.2, Lot PT 12291, Persiaran Cakerawala, Section U4, 40150, Shah Alam, Selangor, Malaysia. Email: prihadi.k@help.edu.my

\section{INTRODUCTION}

Competitiveness is considered an essential element in both education and industry because studies over a decade had been reported its significant contribution to motivation [1], innovation [2], competence [3], achievement [4], corporate performance [5], and positive stress [6]. The aforementioned traits seem to be important to be acquired by university students; thus, it is significant to investigate how competitiveness can be improved.

One of the factors of competitiveness is self-efficacy [7], because it refers to the person's own perceptions of his or her competence and ability to be involved in any form of competition. In general, self-efficacy was defined as belief in one's capabilities to carry out behaviours that are necessary to accomplish a task successfully with the skills they currently possess [8-10]. Thus, it can be assumed that when individuals hold a belief that they are capable of accomplishing things, they will be more competitive in that particular field.

Competitiveness is also determined by various factors such as competence development, development of mature interpersonal relationship, and emotion management [11]. Similarly, some senses that are related to the aforementioned elements, such as senses of mastery, relatedness and emotional reactivity determined resilience among adolescents [12]. Link between resilience and competitiveness have also been reported in other fields such as sports [13], and business [14]. Additionally, it was also reported that selfefficacy is a predictor of resilience [15-17]. Therefore, self-efficacy predicts both competitiveness and resilience, which in other words, individuals who belief in their own capabilities tend to be competitive and at the same time, will bounce back to the competition when they were taken down. 
The aforementioned reports lead to an assumption that when individuals improve their levels of selfefficacy, they tend to develop higher competitiveness as long as they possess adequate levels of resilience. Moreover, the assumption fits the criteria listed by Baron and Kenny for a mediation model. Therefore, it is hypothesized that resilience mediates the prediction of self-efficacy on competitiveness [18].

\subsection{Competitiveness}

Competitiveness is conceptualised as personality trait that affects social interaction in personal and professional life [19], [20]. It is also described as a strong feeling of wanting to win in interpersonal situation as well as be better than others [21], [22]. People that are highly competitive would constantly monitor their performance to ensure that they are surpassing their peers [23].

Studies over decades have reported mixed results on whether competitiveness can be altered. Grill \& Deeter reported that competitiveness is a trait, therefore it is not an ability that could be adapted [20]. In contrast to that study, several studies reported that competitiveness is shaped base on personality and environment [23], [17]. Thus, it is suggested that competitiveness could be altered in various settings.

It is advocated that competitiveness might associated with self-efficacy. Research suggested that self-efficacy belief predicts school achievement [24], [25], and academic effort [26]. In other words, selfefficacy plays a role in altering competitiveness in academic achievement. A study in Malaysia indicated that when individuals are over-dependent on preferential policies (low self-efficacy), they will be less competitive compared to others [27]. Researchers also argued that individuals who are over-dependent for privileges will eventually lead to low competitiveness [28], [29].

Furthermore, competitiveness can be divided into two distinct constructs, the first one is superiority competitiveness (SC) and mastery competitiveness (MC) [30]. It was explained that people with SC tend to see competitions as an avenue to outperform others, while those with MC tend to see it as opportunity to outperform themselves in the past. These two types of competitiveness can have different implication towards students' life and it can be linked differently with other variables in this current study.

\subsection{Self-Efficacy}

Self-efficacy is defined differently by different authors; however, it can be condensed as a belief of self-confidence in their capabilities in executing certain task with a set of skills [8], [26][31][32]. According to Bandura, there are four sources of self-efficacy which are mastery experiences, vicarious experiences, verbal persuasion and physiological states [8].

Extensive research over decades reported that self-efficacy plays an essential role in human achievement in different settings, including education, health, sports and business [8], [33]. High levels of self-efficacy would lead to individuals performing better [35], being more persistent, have better management of their anxiety [36], work harder when faced with failure as well as coping more effectively with harsher cognitive demands. Taylor and Reyes [37], suggested that high academic achievers are posses with high self-efficacy and resilience.

Research over decades have constantly cited self-efficacy as a predictor of resilience and ascribed to various levels of resilience [38-40]. Lightsey's theory proposed that individuals' self-efficacy is the primary predictor to their level of resilience [41]. This theory is supported by an empirical study suggesting positive relationship between self-efficacy and resilience among high school students [42]. Past study had also reported that self-efficacy is a significant predictor of resilience [43].

\subsection{Resilience}

Resilience has been defined differently over decades, in general, it refers to the ability to have positive adaptation in the face of adversity [44-46]. Resilience could be characterized as a trait or a state or combination of both [47].

High levels of resilience have been associated with lower vulnerability to daily stressors because it serves as a buffer to them [48], [49], mitigating depression symptoms [50], improving life satisfaction [51]. In the context of academic, it helps student to recover from failures. Academically resilient students are usually academically successful despite their background [52].

Past studies have suggested that resilience might related to self-efficacy and competitiveness. It is reported that individual with high levels of hardiness (an encompassing term of resilience [53]) usually characterized with high self-efficacy [54]. There has been less research focusing on academic resilience [16], as most studies focuses on business context. However, past study reported that resilience might contribute to academic success, which requires competitiveness to achieve [54]. 


\subsection{Mediation Role of Resilience}

It is advocated that presence or absence of resilience could affect an individuals' decision in life event [56]. Previous studies have reported that resilience is linked to self-efficacy. The aforementioned literatures [42][43], have empirically proven that self-efficacy is a significant predictor of resilience. When social cognitive variables (self-efficacy) combine with personality (resilience), and environment (competitive), it could affect an individual's goal such as academic success [57], [58].

The relationship between resilience and competitiveness has been widely studied in business context [59-61]. In education context, it is suggested that scholarship is one of the factors promoting academic success [62]. Students in university need to compete to be at the top to meet the requirement for scholarship. If a student failed to do so at the first time, s/he will never try again for the scholarship.

\section{RESEARCH METHOD}

Population of this study is university students, and snowball sampling was utilized in this current study in order to recruit the number suggested by the $G^{*}$ Power. One hundred and thirty-six (136) university students were recruited from several private universities in Malaysia. Recruitment was done by uploading the link to the Google form of the scales. The link was uploaded in the social media, such as Facebook, Twitter, and WhatsApp Groups. Participants were also asked to pass the link to their social networks.

The data was collected by utilizing online Google form. The variable X (self-efficacy) is measured by utilizing an adapted version of self-efficacy scale (8 items) [63]. Variable Y (Competitiveness) an adapted version of Personal Development Competitive Attitude Scale (15 items) [64]. Variable M (Resilience) is measured by utiliing adapted version version of brief resilience scale (6 items) [65]. The data collected were analyzed by using SPSS with PROCESS Macro and multiple regression in order to see the mediation result.

\section{RESULTS AND DISCUSSION}

This study aimed to test the hypothesis: Resilience mediates the relationship between self-efficacy and competitiveness. The result suggested that resilience fully mediate the relationship between self-efficacy and competitiveness. PROCESS Macros 3 has been utilized in order to analyse the data, and the results are summarized in Table 1.

Table 1. Summary of the mediation analysis

\begin{tabular}{lllll}
\hline & $\begin{array}{l}\text { Path c } \\
\text { Self-efficacy on } \\
\text { Competitiveness }\end{array}$ & $\begin{array}{l}\text { Path a } \\
\text { Self-efficacy on } \\
\text { Resilience }\end{array}$ & $\begin{array}{l}\text { Path b } \\
\text { Resilience on } \\
\text { Competitiveness }\end{array}$ & $\begin{array}{l}\text { Path c } \\
\text { Self-efficacy and } \\
\text { competitiveness on Resilience } \\
\text { (Controlled for Resilience) }\end{array}$ \\
\hline F & $\mathrm{F}(2,134)=11.42$ & $\mathrm{~F}(1,135)=32.16$ & $\mathrm{~F}(2,134)=11.42$ & $\mathrm{~F}(1,135)=7.71$ \\
Beta & .31 & .41 & .78 & .63 \\
R2 & .17 & .28 & .17 & .10 \\
Sig & .184 & $<.001$ & .001 & .006 \\
\hline
\end{tabular}

Table 1 illustrates the results of the mediation analysis by PROCESS Macro on SPSS. Path c indicates the insignificant prediction of self-efficacy on competitiveness $\left[\mathrm{F}(2,134)=11.42 ; \beta=.038 ; \mathrm{R}^{2}=.131 ; \mathrm{p}\right.$ $=.184]$, which can be conceptualized as the students' belief in their capability does not predict their competitiveness. Statistically speaking, when their belief on their own capability improved by 1 point, their competitiveness will increase by 0.31 point, and $17 \%$ of the increase in competitiveness can be explained by the self-efficacy improvement.

Path a indicates the significant prediction of self-efficacy on resilience $[F(1,135)=32.16 ; \beta=.41$; $\left.\mathrm{R}^{2}=.28 ; \mathrm{p}<.001\right]$. In other words, the students' belief in their capability predicts their being resilient. Statistically speaking, when their belief on their own capability improved by 1 point, their competitiveness will increase by 0.41 point, $28 \%$ of the increase in resilience can be explained by the self-efficacy improvement, and the improvement is significant.

Another part of Table 1 explained that path c', which illustrates how the interaction between selfefficacy and resilience predicts competitiveness. In that particular path, it was shown that when resilience is controlled, self-efficacy significantly predicts competitiveness $\left[F(1,135)=7.71 ; \beta=.63 ; R^{2}=.10 ; p=.006\right]$, their competitiveness will increase by 0.63 point, where $10 \%$ of the significant increase of competitiveness can be explained by the increase of self-efficacy. The following Table 2 shows the result of bias-corrected bootstrap confident interval that confirms the occurrence of indirect effect of self-efficacy on competitiveness through resilience. 


\begin{tabular}{ccccc}
\multicolumn{4}{c}{ Table 2. R-squared mediation effect size (R-sq_med) } \\
\hline & Effect & Boot SE & Boot LLCI & Boot ULCI \\
\hline Resilience & .0850 & .0445 & .0177 & .1987 \\
\hline
\end{tabular}

Table 2 shows a bias-corrected bootstrap confidence interval for the indirect effect $(b=0.32)$ based on 5000 bootstrap samples did not contain zero, BCa CI $(0.018,0.200)$, hence the indirect effect of selfefficacy on competitiveness through resilience is significant, indicating that mediation likely occurred. Table 3 confirms the significance of the mediation.

Table 3 shows that the Sobel test has confirmed the significance of resilience on the link between the self-efficacy and competitiveness $b=.32, Z=2.90, p=.004$. Because the control of resilience changed the significance of self-efficacy (from insignificant to significant), it can be concluded that full mediation had occurred; resilience fully mediates the prediction of self-efficacy on competitiveness, and the result has been confirmed by Sobel test. This finding supports the hypothesis proposed in the earlier part of this paper.

Table 3. Sobel test of the mediation

\begin{tabular}{cccc}
\hline Effect & SE & $\mathrm{Z}$ & $\mathrm{p}$ \\
\hline .3212 & .1106 & 2.9033 & .0037 \\
\hline
\end{tabular}

Findings of this study indicated that a resilience fully mediates the link between self-efficacy and competitiveness. The link between the self-efficacy and competitiveness was found to be insignificant, but when the resilience is controlled (nullified), it was indicated that self-efficacy significantly predicts competitiveness. In other words, the connection between the students' belief on their abilities and their competitiveness is mediated by their resilience; it can be conceptualized that if students believe in their ability to complete a task, and they are ready to bounce back when they lose, they become more competitive than those who are not ready to bounce back. However, this finding was based on the limited because the nature of competitiveness is unknown. As competitiveness can be divided into Mastery and Superiority Competitiveness [30], further study should be conducted in the future in order to know which type of competitiveness is predicted by self-efficacy and mediated by resilience.

Furthermore, it was suggested that self-efficacy is a significant predictor of resilience. The result is in line with Lightsey's theory [41], and reports from several [15-17], which proposed that self-efficacy is central to level resilience. In other words, developing students' self-efficacy might lead them to be able to bounce back to the competition after being taken down by some adversities. Nevertheless, there is a limitation in this study regarding this context; the data in resilience has been collected by self-reporting method, thus the participants might have various understanding and perception about adversities. Some of the participants might have overcome some adversities that are much more intense than the others yet reporting some resilience while others might have experienced much lighter challenges yet reporting low scores in resilience. Similar limitation is also acknowledged $n$ term of self-efficacy; self-report method might be perceived differently among the participants due to their personal differences. Therefore, it is suggested for the future research to control the level of adversities the participants have gone through in order to measure resilience and self-efficacy in a more accurate way.

\section{CONCLUSION}

Overall, this study suggests that resilience mediate the relationship between self-efficacy and resilience. Results of this study are in line with most of the previous studies and theories, and therefore, it is suggested for future research to conduct similar studies in qualitative method in order to obtain richer data of the phenomenon. This finding is significant for the body of knowledge of educational psychology because it provides further knowledge on how to improve healthy competition among university students by improving their sense of competitiveness, resilience and self-efficacy.

\section{ACKNOWLEDGEMENTS}

This paper is part of a larger study funded by Internal Research Grant Scheme from ELM Business School, HELP University, Subang 2, Malaysia.

IJERE Vol. 7, No. 4, December 2018: 279-284 


\section{REFERENCES}

[1] Slowiak, J.M. Self-solicited feedback: Effects of hourly pay and individual monetary incentive pay. Michigan: ProQuest LLC. 2008.

[2] Boldrin, M., \& Levine, D. K. Perfectly competitive innovation. Journal of Monetary Economics, 55(3), 435-453; 2008.

[3] Hansen, J. M., McDonald, R. E., \& Mitchell, R. K. Competence resource specialization, causal ambiguity, and the creation and decay of competitiveness: The role of marketing strategy in new product performance and shareholder value. Journal of the Academy of Marketing Science, 41(3), 300-319; 2013.

[4] Urbancova, H. Competitive advantage achievement through innovation and knowledge. Journal of Competitiveness, 5(1); 2013.

[5] Saeidi, S. P., Sofian, S., Saeidi, P., Saeidi, S. P., \& Saaeidi, S. A. How does corporate social responsibility contribute to firm financial performance? The mediating role of competitive advantage, reputation, and customer satisfaction. Journal of business research, 68(2), 341-350; 2015.

[6] Buser, T., Dreber, A., \& Mollerstrom, J. The impact of stress on tournament entry. Experimental Economics, 20(2), 506-530; 2017.

[7] Krishnan, B. C., Netemeyer, R. G., \& Boles, J. S. Self-efficacy, competitiveness, and effort as antecedents of salesperson performance. Journal of Personal Selling \& Sales Management, 22(4), 285-295; 2002.

[8] Bandura, A. Self-efficacy: toward a unifying theory of behavioral change. Psychological Review, 84(2), 191; 1977.

[9] Bandura, A.. The explanatory and predictive scope of self-efficacy theory. Journal of Social and Clinical Psychology, 4(3), 359-373; 1986.

[10] Bandura, A., \& Wessels, S. Self-efficacy (pp. 4-6). W.H. Freeman \& Company; 1997.

[11] Sawitri, D. R., \& Ariati, J. Self-Regulation Training As An Effort to Enhance Students Competitiveness. 2011.

[12] Villasana, Mercedes, Jesús Alonso-Tapia, and Miguel A. Ruiz. "Personal factors underlying resilience in adolescence: Cross-cultural validity of the Prince-Embury model." The Spanish Journal of Psychology 20; 2017.

[13] Sarkar, M., \& Fletcher, D. Psychological resilience in sport performers: a review of stressors and protective factors. Journal of Sports Sciences, 32(15), 1419-1434; 2014.

[14] Dewi. F. "Manager Characteristics, HR renewal, marketing strategies, partnership motivation, work orientation, work standardization, on SMES business resilience in the competition: A SMES study in Jakarta Indonesia". Scholedge International Journal of Management \& Development ISSN 2394-3378; Vol 3, No 2; 32-48; 2016.

[15] Hamill, S. K. "Resilience and self-efficacy: The importance of efficacy beliefs and coping mechanisms in resilient adolescents". Colgate University Journal of the Sciences, 35(1), 115-146; 2003.

[16] Martin, A. J., \& Marsh, H. W. "Academic resilience and academic buoyancy: Multidimensional and hierarchical conceptual framing of causes, correlates and cognate constructs". Oxford Review of Education, 35(3), 353-370; 2009.

[17] Kususanto, P. "Utilizing "Traders" Board Game to Improve Entrepreneurship Factors among Teenagers: A Qualitative Study”. Jurnal Psikologi Malaysia, 29(2); 2015.

[18] Baron, R. M., \& Kenny, D. A. "The moderator-mediator variable distinction in social psychological research: Conceptual, strategic, and statistical considerations". Journal of Personality and Social Psychology, 51(6), 1173; 1986.

[19] Houston, J. M., Carter, D., \& Smither, R. D. "Competitiveness in elite professional athletes". Perceptual and Motor Skills, 84(3_suppl), 1447-1454; 1997.

[20] Grill, D.L. \& Deeter, T. "Development of the sport orientation questionnaire". Research Quarterly for Exercise and Sport, 59, 191-202; 1988.

[21] Kohn, A. No contest. Boston: Hough-ton Miffins; 1986.

[22] Krishnan, B. C., Netemeyer, R. G., \& Boles, J. S. "Self-efficacy, competitiveness, and effort as antecedents of salesperson performance”. Journal of Personal Selling \& Sales Management, 22(4), 285-295; 2002.

[23] Dumblekar, V. "Interpersonal competitiveness - a study of simulation". 2010.

[24] Moos, D. C., \& Azevedo, R. "Self-efficacy and prior domain knowledge: to what extent does monitoring mediate their relationship with hypermedia learning?". Metacognition and Learning, 4(3), 197; 2009.

[25] Robbins, S. B., Lauver, K., Le, H., Davis, D., Langley, R., \& Carlstrom, A. "Do psychosocial and study skill factors predict college outcomes? A meta-analysis". Psychological Bulletin, 130(2), 261; 2004.

[26] Komarraju, M., \& Nadler, D. Self-efficacy and academic achievement: Why do implicit beliefs, goals, and effort regulation matter?. Learning and Individual Differences, 25, 67-72; 2013.

[27] Yeoh, J. P. S., \& Yeoh, P. A. "Competitiveness between Ethnic Malays and Ethnic Chinese in Malaysia". GSTF Journal of Psychology (JPsych), 2(1); 2018.

[28] Haque, M.S. "The role of the state in managing ethnic tensions in Malaysia: A critical discourse". American Behavioral Scientist, 47, 240-266; 2003.

[29] Stafford, G. "Economics and ethnicity: Why Malaysia will not follow the Indonesian example of racial relations. Paper presented". at the 2nd International Malaysian Studies Conference, University of Malaya, Kuala Lumpur, Malaysia; 1999.

[30] Kayhan, E. "Two Facets of Competitiveness and their Influnce on Psychological Adjustment, Achievement, and Decision-Making”, 2003.

[31] Skaalvik, E. M., \& Skaalvik, S. "Teacher self-efficacy and perceived autonomy: Relations with teacher engagement, job satisfaction, and emotional exhaustion”. Psychological Reports, 114(1), 68-77; 2014. 
[32] Piperopoulos, P., \& Dimov, D. "Burst bubbles or build steam? Entrepreneurship education, entrepreneurial selfefficacy, and entrepreneurial intentions". Journal of Small Business Management, 53(4), 970-985; 2015.

[33] Chen, Y., Zhang, Q., \& Lu, J. "A correlative study on mental health and course of study perceived self-efficacy of nursing students [Chinese]”. Chinese Nursing Research, 22(9B), 2362-2364; 2008.

[34] Levett-Jones, T., Lathlean, J., Higgins, I., \& McMillan, M. "The duration of clinical placements: a key influence on nursing students' experience of belongingness". Australasian Journal of Advanced Nursing, 25(2), 8-16; 2008.

[35] Forbes, D. P. "Are Some Entrepreneurs More Overconfident than Others?," Journal of Business Venturing 20(5), 623-640; 2005.

[36] Zimmerman, B. J. "Self-efficacy: An essential motive to learn". Contemporary Educational Psychology, 25(1), 82-91; 2000.

[37] Taylor, H., \& Reyes, H. "Self-efficacy and resilience in baccalaureate nursing students". International Journal of Nursing Education Scholarship, 9(1), 1-13; 2012.

[38] Anthony, E. J. "The syndrome of the psychologically invulnerable child. In E. J; 1974

[39] Rutter, M. "Resilience: some conceptual considerations". Journal of Adolescent Health; 1993.

[40] Earvolino-Ramirez, M. "Resilience: A concept analysis". Nursing Forum 42, 73-82; 2007.

[41] Lightsey, O. R. "Resilience, meaning, and well-being". The Counselling Psychologist, 34, 96-107; 2006.

[42] Speight, N. P. "The relationship between self-efficacy, resilience and academic achievement among African American urban adolescents". Doctoral Dissertation, Washington DC: Howard University; 2009.

[43] Keye, M. D., \& Pidgeon, A. M. "Investigation of the relationship between resilience, mindfulness, and academic self-efficacy". Open Journal of Social Sciences, 1(06), 1; 2013.

[44] Garmezy, N., \& Masten, A. S. "The protective role of competence indicators in children at risk". 1991.

[45] Tedeschi, R.G. \& Calhoun, L.G. "Posttraumatic growth: Conceptual foundations and empirical evidence". Psychological Inquiry, 15(1), 1-18; 2004.

[46] Abiola, T., and Udofia, O. "Psychometric assessment of the Wagnild and Young's resilience scale in Kano, Nigeria". BMC Res. Notes4:509; 2011. doi: 10.1186/1756-0500-4-509

[47] Wagnild, G. "A review of the Resilience Scale". Journal of Nursing Measurement, 17(2), 105-113; 2009.

[48] Pengilly, J. W., \& Dowd, E. T. "Hardiness and social support as moderators of stress". Journal of Clinical Psychology, 56(6), 813-820; 2000.

[49] Almeida, David M. "Resilience and vulnerability to daily stressors assessed via diary methods." Current Directions in Psychological Science 14.2: 64-68; 2005.

[50] Wingo, A. P., Wrenn, G., Pelletier, T., Gutman, A. R., Bradley, B., \& Ressler, K. J. "Moderating effects of resilience on depression in individuals with a history of childhood abuse or trauma exposure". Journal of Affective Disorders, 126(3), 411-414; 2010.

[51] Cohn, M. A., Fredrickson, B. L., Brown, S. L., Mikels, J. A., \& Conway, A. M. "Happiness unpacked: positive emotions increase life satisfaction by building resilience". Emotion, 9(3), 361; 2009.

[52] Erberber, E., Stephens, M., Mamedova, S., Ferguson, S., \& Kroeger, T. "Socioeconomically Disadvantaged Students Who Are Academically Successful: Examining Academic Resilience Cross-Nationally". Policy Brief No. 5. International Association for the Evaluation of Educational Achievement. 2015.

[53] Kumpfer, K. "Factors and processes contributing to Resilience. The resilience framework". In M. D. Glantz and J. L. Johnson (Eds.), Resilience and Development: Positive Life Adaptations. Academic/Plenum Publishers, NY, pp. 179-114; 1999.

[54] Likhacheva, E. V., Ognev, A. S., \& Kazakov, K. A. "Hardiness and purposes in life of modern Russian students". Middle East Journal of Scientific Research, 14(6), 795-798. 2013.

[55] Çelik, D. A., Çetin, F., \& Tutkun, E. "The role of proximal and distal resilience factors and locus of control in understanding hope, self-esteem and academic achievement among Turkish pre-adolescents". Current Psychology, 34(2), 321-345; 2015.

[56] Faircloth, A. L. "Resilience as a Mediator of the Relationship between Negative Life Events and Psychological Well-Being". 2017.

[57] Lent, R.W. \& Brown, S.D. "Social cognitive approach to career development: An overview". Career Development Quarterly, 44(4), 310-321; 1996.

[58] Bullough, A., Renko, M., \& Myatt, T. "Danger zone entrepreneurs: The importance of resilience and self-efficacy for entrepreneurial intentions". Entrepreneurship Theory and Practice, 38(3), 473-499; 2014.

[59] Jorgensen, A.L. and Knudesen, J.S. "Sustainable competitiveness in global value chains: how do small Danish firms behave". Corporate Governance, 8 (4), 449-462; 2006.

[60] Gunasekaran, A., Subramanian, N., \& Rahman, S. "Supply chain resilience: role of complexities and strategies". 2015.

[61] Gunasekaran, A., Rai, B. K., \& Griffin, M. "Resilience and competitiveness of small and medium size enterprises: an empirical research". International Journal of Production Research, 49(18), 5489-5509; 2011.

[62] Breitenstein, D. "Asian students carry high expectations for success". USA Today. 2013.

[63] Biemann, T., Kearney, E., \& Marggraf, K.’'Empowering leadership and managers' career perceptions: Examining effects at both the individual and the team level". The Leadership Quarterly, 26(5), 775-789; 2015.

[64] Ryckman, R. M., Hammer, M., Kaczor, L. M., \& Gold, J. A. "Construction of a personal development competitive attitude scale". Journal of Personality Assessment, 66(2), 374-385; 1996.

[65] Smith, B. W., Dalen, J., Wiggins, K., Tooley, E., Christopher, P., \& Bernard, J. "The brief resilience scale: assessing the ability to bounce back". International Journal of Behavioral Medicine, 15(3), 194-200; 2008. 